\title{
Neonatal thrombocytopenia: A review. II. Non-immune thrombocytopenia; platelet transfusion
}

\author{
Hugo Donato, M.D. ${ }^{a}$
}

\begin{abstract}
Non-immune thrombocytopenia is caused by multiple pathologies; the most common causes are extra- or intrauterine infections, whereas secondary cases result from other pathologies involved in the fetal-placentalmaternal interface. This second article lists its causes and provides details of the different pathologies. Platelet transfusion is widely used in neonatology, both as treatment and as bleeding prophylaxis. However, there is no general consensus about the platelet count threshold that is convenient to indicate a transfusion or actual indications. Recent articles are commented regarding the different proposed strategies. The emphasis is on discussing the multiple adverse effects of platelet transfusions because knowledge about them is changing the paradigm for indications, suggesting that a much more restrictive policy is required.

Key words: thrombocytopenia, newborn infant, infections, platelet transfusion, bleeding.
\end{abstract}

http:/ / dx.doi.org/10.5546/ aap.2021.eng.e303

To cite: Donato H. Neonatal thrombocytopenia: A review. II. Non-immune thrombocytopenia; platelet transfusion. Arch Argent Pediatr 2021;119(4):e303-e314.

a. Private Outpatient Pediatric Hematology Offices. Autonomous City of Buenos Aires, Argentina.

E-mail address:

Hugo Donato, M.D.: hcdonato@gmail.com

Funding:

None.

Conflict of interest: None.

Received: 8-27-2020 Accepted: 10-30-2020

\section{NON-IMMUNE}

\section{THROMBOCYTOPENIA}

Non-immune thrombocytopenia may be the result of increased platelet destruction, decreased platelet production or a mixed mechanism. In some cases, the causative mechanism is still unknown.

\section{Perinatal infections}

These are the most common cause of thrombocytopenia in newborn infants. Any bacterial, viral or fungal infection may lead to a reduction in platelet count (PC). ${ }^{1}$ It is estimated that $54-80 \%$ of infected neonates develop thrombocytopenia, with no evidence of disseminated intravascular coagulation (DIC) in more than half of cases..$^{2-4}$ This is basically due to an increased platelet destruction that may coexist with decreased synthesis (Figure 1). ${ }^{1,5,6}$

The reduction in PC occurs early; it may even precede the onset of infection symptoms and, in general, it lasts for approximately one week..$^{2-4}$ If thrombocytopenia occurs alone and not in association with DIC, it is usually not severe and bleeding manifestations are minimal. ${ }^{1}$

\section{Necrotizing enterocolitis}

Thrombocytopenia is almost always present in this clinical condition; it is observed in 80$90 \%$ of affected neonates, without associated DIC. PCs usually range between 30 and $60 \times 10^{9} / \mathrm{L}$, and may cause moderate to severe bleeding manifestations. ${ }^{1}$

Thrombocytopenia is considered a predictor of poor prognosis. ${ }^{9}$ It is due to increased destruction with an unknown cause, although a suppressed production may also be involved. ${ }^{10,11}$ Routine treatment implies platelet transfusions (PT) to maintain a safe $\mathrm{PC}$, although some studies have questioned its indication in this pathology. ${ }^{12-14}$

\section{Intrauterine infections}

These are one of the most common 
causes of thrombocytopenia, in general associated with anemia and/or neutropenia, and, other times, they are part of DIC. ${ }^{5}$ Thrombocytopenia may be caused by increased destruction, decreased synthesis or both mechanisms together. Typically, petechiae occur since the first day of life and may last for weeks or months.

Cytomegalovirus is the most common intrauterine infection, occurring in $0.2-25 \%$ of fetuses. ${ }^{16-18}$ Thrombocytopenia is observed in $36-70 \%$ of cases. ${ }^{19-21}$ Sometimes, it is the only manifestation of congenital cytomegalovirus infection. Petechiae are rarely present at birth; in general, they appear a few hours after and disappear within weeks. Any petechial rash that may be observed may not necessarily be associated with thrombocytopenia.

It is typical to note an almost total lack of megakaryocytes in the bone marrow due to the direct action of cytomegalovirus on them, so the main mechanism involved is decreased platelet production. ${ }^{19,22,23}$ There is also plenty evidence of an increased platelet destruction, either secondary to DIC, antibodies or hypersplenism. ${ }^{16,24-26}$

Between $40 \%$ and $80 \%$ of neonates with rubella develop thrombocytopenia. ${ }^{27-34}$ At birth, the PC is usually below $50 \times 10^{9} / \mathrm{L}$ and, in general, it goes back to normal spontaneously towards the end of the second week, although it may last up to 2 months. ${ }^{19,29,35}$ Its clinical manifestations include purpura, which is more severe in the first hours of life; severe bleeding is very rare ${ }^{19}$ A noticeable reduction in megakaryocytes is observed in the bone marrow, which evidences that synthesis suppression is the main mechanism involved..$^{15,33}$

In other infections, the causative mechanism is increased destruction. In the case of syphilis, anemia is the most common hematologic manifestation, but associated thrombocytopenia is observed in $28-45 \%$ of patients. ${ }^{36,37}$ In the case of toxoplasmosis, thrombocytopenia is also less frequent than anemia, and it is observed in approximately $10 \%$ of neonates. ${ }^{19,38} \mathrm{In}$ enterovirus infection, DIC is the most common

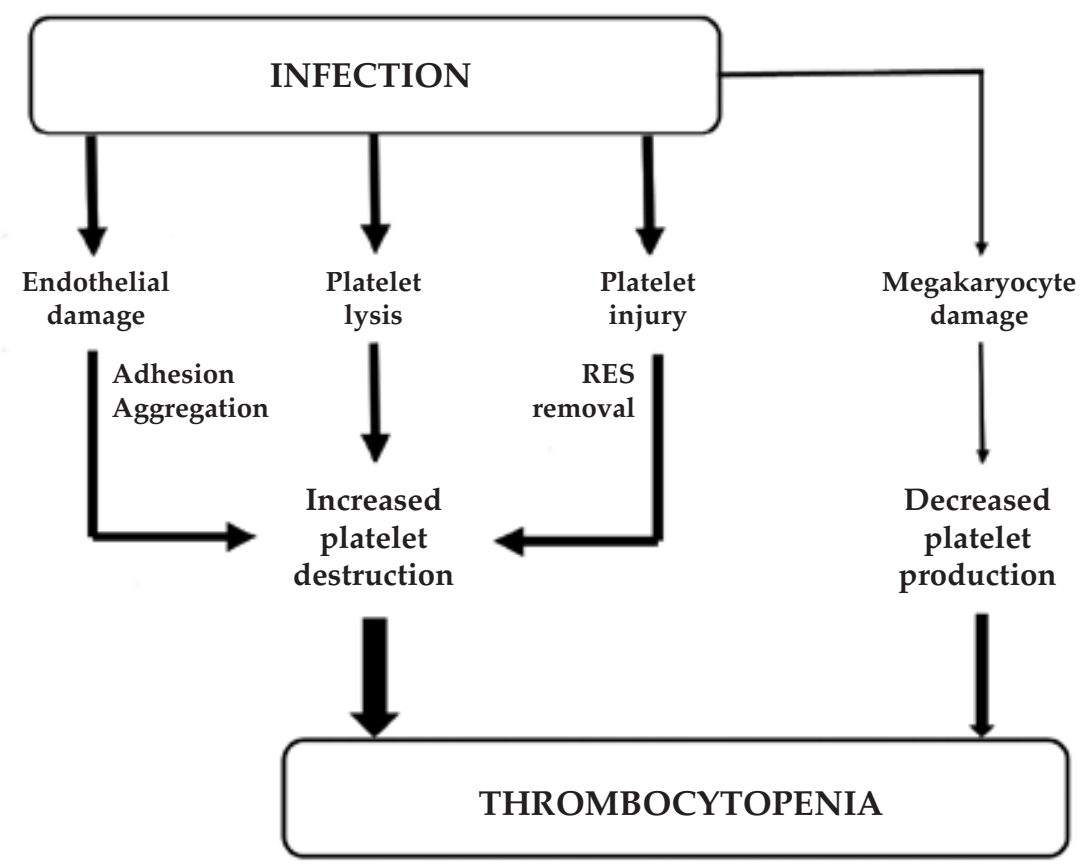

RES: reticuloendothelial system.

Production mechanisms are multiple. The main one is increased platelet destruction, which is mediated by several pathways. Platelets may be directly destroyed by the microorganism or damaged for the subsequent removal by the reticuloendothelial system. The endothelium may also be damaged, leading to endothelial adhesion and platelet aggregation. In addition, decreased platelet synthesis may occur due to the direct damage of the microorganism on megakaryocytes, which is evidenced by the decreased number of megakaryocytes and/or increased circulating thrombopoietin levels.

Source: Developed by the author. 
manifestation, and bleedings secondary to DIC are one of the most important causes of death. ${ }^{39-42}$ Isolated thrombocytopenia may be observed in approximately $17 \%$ of patients. ${ }^{40}$ In herpes virus infection, thrombocytopenia caused by DIC is also the most common hematological alteration, present in $40-50 \%$ of cases, and is an indicator of poor prognosis. ${ }^{19,43-46}$ Approximately $86 \%$ of neonates with hydrops fetalis secondary to severe anemia due to parvovirus B19 infection have thrombocytopenia. ${ }^{47}$

\section{Thrombotic microangiopathy}

Thrombotic microangiopathy (TMA) syndromes are characterized by thrombocytopenia, hemolytic anemia, and fragmented red cells. The most common cause is DIC, which may be triggered by multiple pathologies associated with acidosis, hypoxia and / or shock. ${ }^{48-50}$ Congenital thrombotic thrombocytopenic purpura caused by partial or total deficiency in ADAMTS13, a protease that cleaves von Willebrand factor, ${ }^{51}$ and atypical hemolytic uremic syndrome, caused by complement deregulation, are two rare, but very severe, conditions that should be considered in any neonate with TMA without evident cause..$^{52-54}$

\section{Giant hemangioma}

Thrombocytopenia secondary to giant hemangioma (Kasabach-Merritt syndrome) may or may not be accompanied by bleeding. These cases correspond to congenital hemangioendotheliomas evident since birth. In

FIGURE 2. Potential therapeutic interventions in Kasabach-Merritt syndrome

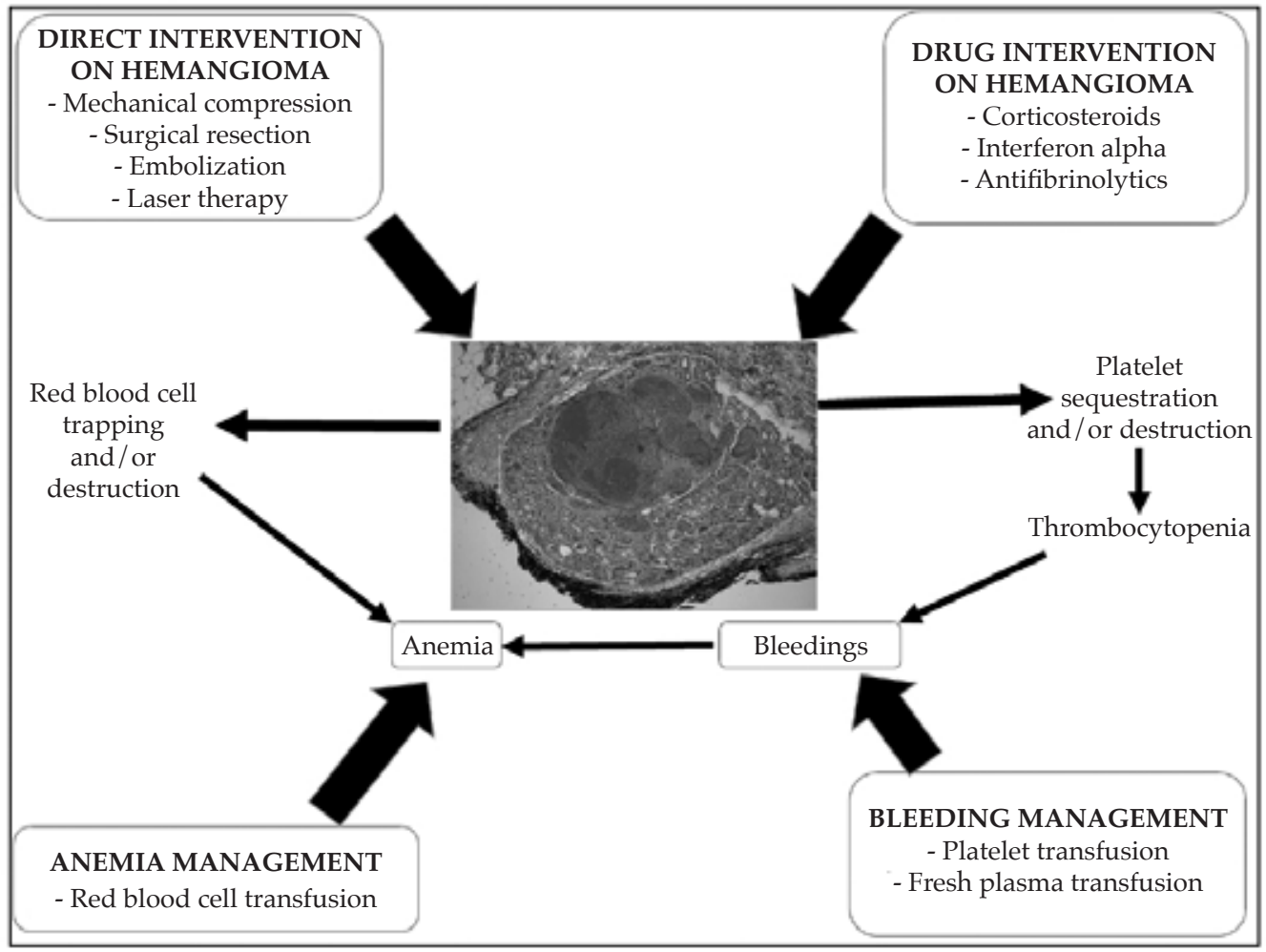

When, due to location or severity, an active drug management for hemangioma is decided, corticosteroids are the first option, although their usefulness is doubtful. Interferon alpha, which has an inhibitory effect on angiogenesis, has shown good results, although it is not always effective and may cause major adverse reactions. It is indicated if corticosteroid therapy has failed. Direct intervention on the hemangioma may be through surgical resection, embolization or laser therapy, with varying results and probable development of complications resulting from these procedures. Replacement therapy with platelet, plasma or packed red blood cell transfusion should be individualized for each patient.

Source: Developed by the author. 
general, they are large and occur alone, and may be located in any site, although rarely in organs such as the liver or spleen. ${ }^{55-57}$

Thrombocytopenia takes place through platelet sequestration or destruction inside the tumor mass, and the presence of a DIC process is common. ${ }^{58,59}$ It may coexist with anemia, as a result of bleeding or red blood cell trapping and destruction inside the tumor mass ${ }^{60}$ Treatment should consider that hemangiomas tend to solve spontaneously, so potential risks should be assessed. Figure 2 shows potential therapeutic interventions. ${ }^{60-68}$

\section{Thrombocytopenia secondary to other neonatal pathologies}

Thrombocytopenia has been observed in some cases of severe hyperbilirubinemia after phototherapy for several days, as well as in some neonates with severe $\mathbf{R h}$-hemolytic disease. . $^{6-71}$ This is due to the platelet damage caused by phototherapy. ${ }^{72,73}$ In Rh-hemolytic disease there is probably some additional mechanism related to immune reaction. ${ }^{74}$ Thrombocytopenia is almost never severe. PC is generally between 50 and $150 \times 10^{9} / \mathrm{L}$ and goes back to normal levels within 48 hours after stopping phototherapy. ${ }^{1}$

Some studies have reported that $20-30 \%$ of neonates with polycythemia-hyperviscosity syndrome develop thrombocytopenia, probably in relation to an increase in platelet adhesion and aggregation and a reduced average lifespan. ${ }^{75-77}$ Perinatal respiratory disorders may be associated with thrombocytopenia of varying severity. It is more common in perinatal aspiration syndrome (approximately, $13 \%$ of cases) than in hyaline membrane disease or neonatal asphyxia. ${ }^{78}$ In neonates with intrauterine growth restriction, thrombocytopenia may be present. ${ }^{79}$ It is much more common in preterm than in term newborn infants. ${ }^{1,79,80}$ It is basically caused by a decreased platelet production, but may also result from increased destruction secondary to intrauterine hypoxia or anti-human leukocyte antigen (anti-HLA) antibodies. ${ }^{5,81-84}$ Thrombocytopenia develops in the first days; it is moderate and generally does not last more than 2 weeks. ${ }^{84}$

\section{Thrombocytopenia due to bone marrow occupation}

Thrombocytopenia is the result of a disease occupying the medullary canal and gradually replacing normal bone marrow tissue. It is observed in congenital leukemia, transient myeloproliferative disorder, neuroblastoma, Langerhans cell histiocytosis, and osteopetrosis. It is very uncommon.

\section{Amegakaryocytic thrombocytopenias}

This is a rare disease characterized by the total or partial absence of megakaryocytes in the bone marrow. Congenital amegakaryocytic thrombocytopenia is an autosomal recessive disease characterized by severe thrombocytopenia since birth. ${ }^{85,86}$ It may be caused by mutations in the MPL or THPO genes. ${ }^{87,88}$

Most patients do not have associated physical abnormalities, although micrognathia, microcephaly, congenital heart disease, growth retardation, and maturation disorders have been described. ${ }^{86,89}$ The association with such physical alterations may confound the condition with Fanconi anemia, so a chromosomal fragility test must be performed. Thrombocytopenia develops in the first week of life in more than $50 \%$ of cases. ${ }^{86,90}$

Mortality is high, in general secondary to intracranial hemorrhage. These patients tend to progress to aplastic anemia (50\% of cases), leukemia or myelodysplasia, ${ }^{85,86,89,91}$ so the treatment of choice is hematopoietic stem cell transplantation, which should be done as early as possible; transplantation achieves a survival of more than $90 \% .{ }^{92,93}$ Until the procedure is performed, the patient should be managed with PTs. ${ }^{89,91}$ Treatment with romiplostim, which has proven to be highly effective in 3 children from an affected family, is under study. ${ }^{88}$

Thrombocytopenia with absent radii (TAR) is an autosomal recessive syndrome characterized by the absence of both radii. ${ }^{86}$ It may be associated with other skeletal malformations, especially in the upper limbs, and other organ malformations; the most common ones are congenital heart disease (22-33\%), facial hemangioma (24\%), and kidney abnormalities $(23 \%) .{ }^{86,94-96}$ Thrombocytopenia is severe and develops in the first week of life in $59 \%$ of cases and before 4 months old in $90 \% .{ }^{86,96}$ The mortality rate is approximately $25 \%$, usually due to intracranial hemorrhage, and death occurs in the first months of life. ${ }^{86,90,95}$ As of 1 year old, thrombocytopenia tends to resolve, and remission is achieved by 4 years old in $70 \%$ of cases..$^{91}$ These patients do not progress to pancytopenia and generally do not tend to a malignant change, ${ }^{74,85,86,89,97}$ although isolated cases of leukemia have been reported..$^{98-100}$ Treatment includes periodic PTs to maintain the 
PC above $30 \times 10^{9} / \mathrm{L}^{1,74,89,91,93}$

Amegakaryocytic thrombocytopenia with radio-ulnar synostosis is an autosomal dominant disease behaving similarly to congenital amegakaryocytic thrombocytopenia. It is characterized by the presence of proximal radio-ulnar synostosis and may be associated with clinodactyly, syndactyly, hip dysplasia, and hearing loss. ${ }^{85,91,93}$

Neonatal thrombocytopenia may sometimes account for the initial manifestation of Fanconi anemia and may persist for several years as the only symptom, until pancytopenia, typical of this condition, becomes established. ${ }^{89}$

\section{Inherited hrombocytopenias}

These are syndromes caused by structural platelet alterations. In many cases, platelets also present functional abnormalities. ${ }^{85,101}$ Thrombocytopenia may be associated with the involvement of other hematopoietic lineages or other organs (kidney, ear, eyes, skin, etc.) or progression to a malignancy. This is a group of multiple pathologies, some better known than others, and new syndromes are still being described. ${ }^{85,102}$

Table 1 shows their classifications based on platelet size, which is one of the most practical options. ${ }^{102}$ In general, thrombocytopenia is mild to moderate; only a few cases become severe. Most cases develop after 1 year old and are rare in the neonatal period. The number of megakaryocytes in the bone marrow is normal.

A case of severe neonatal thrombocytopenia has been recently described, initially diagnosed as neonatal alloimmune thrombocytopenia, in a child with a novel mutation related to the MYH-9 gene. ${ }^{103}$ Macrothrombocytopenia is the most frequent type, especially when caused by mutations in the $M Y H-9$ gene, which codes the non-muscle myosin heavy chain IIA. It may be accompanied by other clinical and laboratory manifestations, and it is part of different syndromes that were previously described as different entities, but are currently considered an unique, clinically heterogeneous disease. ${ }^{85,102}$ A typical characteristic of this disease, observed in most cases, is the presence of azurophilic inclusions, similar to Döhle bodies, corresponding to ribosome clusters in the cytoplasm of neutrophils, eosinophils, and monocytes (Figure 3).

\section{Inherited metabolic disorders}

These are exceptionally rare pathologies that may develop with thrombocytopenia since birth. Reported cases included methylmalonic acidemia, ketotic glycinemia, isovaleric acidemia, and acidemia due to holocarboxylase synthetase deficiency. ${ }^{60,104-106}$

\section{Chromosomal abnormalities}

Several alterations, mainly trisomies 13, 18 , and 21 and Turner syndrome may cause neonatal thrombocytopenia. ${ }^{107}$ In a study with 5194 samples of fetal blood, thrombocytopenia was observed in 247 (4.8\%); of these, 43 (17\%) corresponded to fetuses carrying chromosomal disorders. Thrombocytopenia was observed in $26 / 30$ cases of trisomy 18 ; in 6/11 cases of trisomy 13; in 5/ 16 cases of Turner syndrome; in $3 / 4$ cases of triploidy; and in 3/44 cases of trisomy $21 .^{20}$ Thrombocytopenia is usually mild to moderate and does not cause major bleedings. ${ }^{1,20}$

\section{Thrombocytopenias secondary to maternal conditions}

Arterial hypertension (AHT) is observed in $12 \%$ of pregnancies, and is severe in $3 \%$ of them. It is one of the most common causes of neonatal thrombocytopenia. ${ }^{108-111} \mathrm{In}$ a review of 1414 pregnancies with severe HTN, 130 neonates developed thrombocytopenia, but only 5 of them ( $0.4 \%$ of the total) had a PC below $50 \times 10^{9} / \mathrm{L}^{112}$ In general, neonates do not develop bleeding and

TABLE 1. Classification of inherited thrombocytopenias

Large platelets (macrothrombocytopenia)

- MYH9 gene-related conditions

- Bernard-Soulier syndrome

- Gray platelet syndrome

- Platelet-type von Willebrand disease

- GATA1 gene-related conditions

- Paris-Trousseau thrombocytopenia

- Jacobsen syndrome

- Thrombocytopenia associated with sitosterolemia

- FLNA gene-related thrombocytopenia

- TUBB1 gene-related macrothrombocytopenia

Normal platelets

- Familial platelet disorder with predisposition to acute myeloblastic leukemia

- ANKRD26 gene-related thrombocytopenia

- CYCS gene-related thrombocytopenia

Small platelets

- Wiskott-Aldrich syndrome

- X-linked thrombocytopenia 
the PC returns to normal in 5-7 days. ${ }^{74}$ Maternal hyperthyroidism may rarely lead to neonatal thrombocytopenia. ${ }^{113}$

\section{PLATELET TRANSFUSIONS}

Although a PT is a useful procedure in the management of platelet disorders, it is worth noting that there is no direct relationship between severe thrombocytopenia and the onset of bleeding. ${ }^{114-120}$ Some prospective, observational studies showed that bleeding was present in only $9-10 \%$ of neonates with severe thrombocytopenia. ${ }^{115,121}$ In a review of six studies, with the aim of determining if prophylactic transfusion would reduce the risk for bleeding, no evidence of a cause-and-effect relationship between PC and bleeding was observed. ${ }^{122}$

The severity of thrombocytopenia itself is not currently considered the most accurate predictor of the risk for bleeding. There are other parameters to determine both the occurrence and severity of thrombocytopenia, including gestational age, chronological age, the cause of thrombocytopenia, coexistence with other clotting defects, vascular endothelium integrity, metabolic conditions associated with oxidative stress, medications, platelet volume, etc. ${ }^{123}$

Different publications have established that, in case of active bleeding, the decision to indicate a PT is basically determined by the clinical condition, not the PC. ${ }^{124-127}$ Several authors have suggested different indication schedules (Table 2), but there is no general consensus. ${ }^{121,128-132}$

A $10-15 \mathrm{~mL} / \mathrm{kg}$ bank platelet dose or 1 unit of platelets obtained by apheresis is enough to increase the PC by $50-100 \times 10^{9} /$ L. $^{74,123,133}$ Its effectiveness depends especially on the cause and production mechanism of thrombocytopenia. The duration of platelet infusion does not modify the response. ${ }^{134}$

Currently, the main controversy is not related to the management of bleeding but to its prevention, in an attempt to establish the PC threshold below which bleeding would be highly probable and would warrant a prophylactic PT. Such decision is basically based on dogmas and expert opinions, with a minimal support from conclusive scientific data.

In recent years, some studies have provided interesting data. Borges et al. reported a similar incidence of intraventricular hemorrhage comparing $50 \times 10^{9} / \mathrm{L}$ or $100 \times 10^{9} / \mathrm{L}$ thresholds

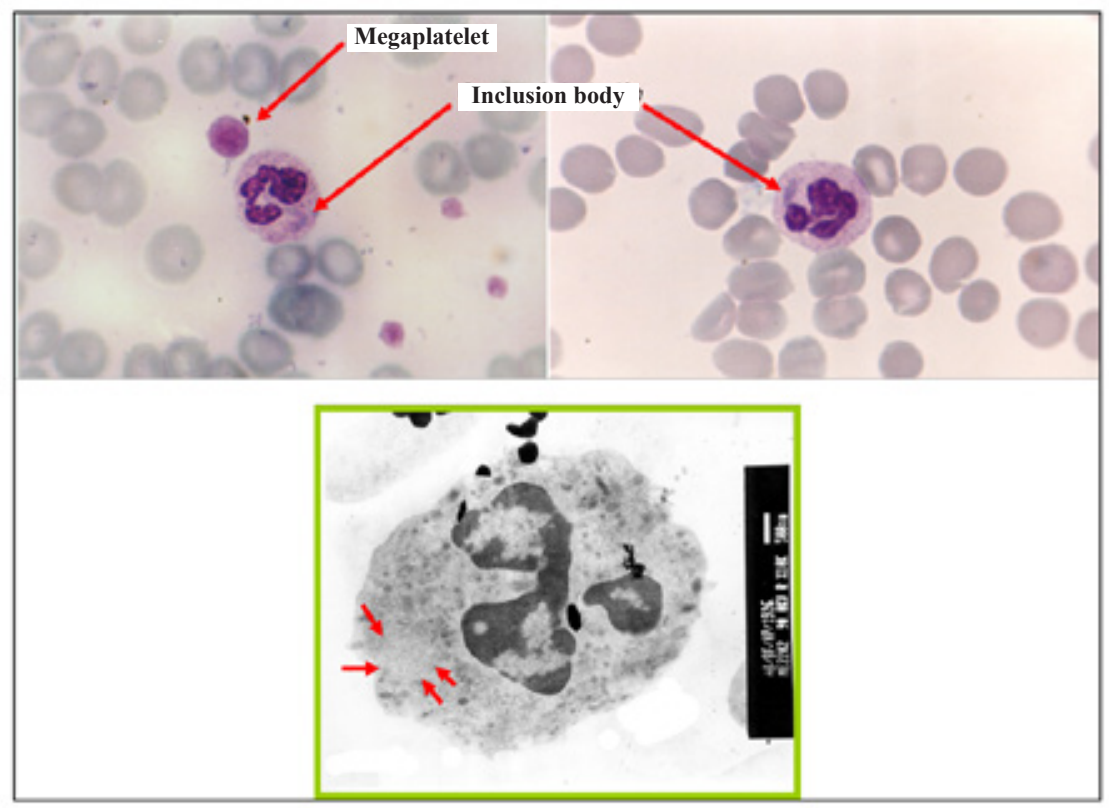

The upper pictures (light microscopy) show a megaplatelet and inclusion bodies in two neutrophils. The lower picture (electron microscopy) shows the ribosome cluster making up the body.

Source: Developed by the author. 
to indicate a PT and suggested that a restrictive guideline was preferable to liberal criteria. ${ }^{135}$ Recently, in an excellent prospective, multicenter study, 660 preterm newborn infants with less than 34 weeks of gestation who had severe thrombocytopenia were randomized to receive a PT with a PC below $50 \times 10^{9} / \mathrm{L}$ (liberal) or $25 \times 10^{9} / \mathrm{L}$ (restrictive). ${ }^{136}$ The results related to the primary objective (death or major bleeding within 28 days) showed a greater mortality or severe bleeding incidence in the group that received the PT based on liberal criteria than in the restrictive guideline group (26\% versus $19 \%$, respectively; $p=0.02$ ). Based on these results, the $25 \times 10^{9} / \mathrm{L}$ platelet threshold seems to be adequate for a prophylactic PT, although it should be taken into account that some authors consider that using this threshold in the first week of life, when the risk for bleeding is at its peak, is arguable. ${ }^{137}$

As a secondary objective, a significantly higher incidence of bronchopulmonary dysplasia (BPD) was also observed in the liberal group. These findings focus the attention on an aspect that has caught the eye of several authors: PTs are not harmless and may cause severe adverse effects. ${ }^{123,138}$ The association between the number of PTs administered and a worse course has been suggested in several prior studies. ${ }^{139-142}$ In 2007, Baer et al., in a retrospective study with 1600 hospitalized neonates, found an association between multiple PTs and a higher mortality rate. ${ }^{13} \mathrm{Du}$ Pont-Thibodeau et al. observed in pediatric patients in the intensive care unit that a prophylactic PT was associated with a higher risk for multiple organ failure, sepsis, nosocomial infections, and mortality. ${ }^{14}$ Similar findings have been reported in adults.

An association has been described between prophylactic PTs in invasive procedures and an increased risk for thrombosis and mortality, between prophylactic PTs in patients with intracranial hemorrhage and a greater mortality and worsening of the neurological condition, between PTs and an increased risk for respiratory distress in patients with major trauma, and between PTs and an increased risk for mortality and complications in patients undergoing myocardial revascularization surgery. ${ }^{143-146}$ However, other studies in adults reported that a prophylactic PT is not associated with a greater risk. ${ }^{147-149}$ A recent systematic review failed to draw conclusive conclusions in this regard. ${ }^{150}$

There is also strong evidence that newborn infants are much more susceptible to experience adverse effects from transfusions. An analysis of the Serious Hazards of Transfusion (SHOT), the United Kingdom's hemovigilance scheme, reported that, over a 10 -year period, there was a disproportionately higher number of adverse effects among neonates compared to pediatric or adult patients receiving transfusions. ${ }^{151}$ In the case of red blood cell transfusions, the number of adverse events in patients younger than 1 year was 37:100 000, whereas in older children it was 18:100 000, and in adults, 13:100 000. Unfortunately, there are still no reliable data specifically related to PTs. Similar findings were reported by the hemovigilance system in Norway. ${ }^{152,153}$

Some mechanisms may help to explain the harmful effects of PTs. The high transfusion volume associated with PT in neonates, especially preterm babies $(15 \mathrm{~mL} / \mathrm{kg})$, is 3-5 times higher than that administered to adults. Such volume, which in a preterm newborn infant with a weight of $1 \mathrm{~kg}$ accounts for approximately $17 \%$ of their blood volume, may theoretically cause adverse hemodynamic effects, including increased cerebral blood flow and cerebral arterial pressure, associated with a greater risk for intracranial hemorrhage. ${ }^{154-156}$ It may also cause complications in neonates with concomitant cardiac involvement. ${ }^{115}$

TABLE 2. Recommended platelet count for platelet transfusion indication, according to different authors

\begin{tabular}{lccccc}
\hline Author & $\begin{array}{c}\text { PNBI } \\
\text { No bleeding } \\
\text { Sick }\end{array}$ & $\begin{array}{c}\text { PNBI } \\
\text { No bleeding } \\
\text { Stable }\end{array}$ & $\begin{array}{c}\text { TNBI } \\
\text { No bleeding } \\
\text { Sick }\end{array}$ & $\begin{array}{c}\text { TNBI } \\
\text { No bleeding } \\
\text { Stable }\end{array}$ & $\begin{array}{c}\text { NBI } \\
\text { Active } \\
\text { bleeding }\end{array}$ \\
\hline Blanchette et al. & $<50$ & $<30$ & $<30$ & $<20$ & $<50$ \\
Calhoun et al. & $<50$ & $<25$ & $<50$ & $<50$ & $<50$ \\
Murray et al. & $<50$ & $<30$ & $<30$ & $<30$ & $<100$ \\
Gibson et al. & $<30$ & $<20$ & $<30$ & $<30$ & $<50$ \\
\hline
\end{tabular}

NBI: newborn infant; PNBI: preterm newborn infant; TNBI: term newborn infant. Platelet counts are indicated as platelets $\times 10^{9} / \mathrm{L}$. 
Another factor to consider is the potential harmful effect of adult platelets transfused to newborn infants given that their platelets are less responsive to platelet agonists, have less alpha-adrenergic receptors on their surface, a reduced calcium mobilization, and differences in thromboxane receptor signaling. ${ }^{157}$ In preterm newborn infants, such platelet hyporeactivity is even more pronounced. ${ }^{158,159}$ It is still unknown to what extent such differences may lead to greater microthrombosis or other adverse effects. ${ }^{155,160,161}$

The transmission of infectious agents should also be taken into consideration because platelets are the blood component most susceptible to contamination given that concentrates are stored at room temperature. ${ }^{162}$ The potential severe adverse effects of transfusions should not be ruled out either (transfusion-related acute lung injury [TRALI], among others), which, given their characteristics, are not easily recognizable in severely-ill newborn infants, so they may be under-recorded. . $^{151,155,162}$ In addition to their hemostatic role, platelets have important proinflammatory and immunomodulatory effects. ${ }^{163,164}$ Considering that the inflammatory component is fundamental in BPD pathophysiology, it is valid to speculate that the proinflammatory effect of PTs may be a mechanism leading to a greater occurrence of BPD. To what extent such proinflammatory activity facilitates the development of other pathologies (short bowel syndrome, liver damage, etc.) is still to be elucidated. . $^{12,165}$

To conclude, the data obtained in recent years have demonstrated that many indicated PTs provide no benefit, are unnecessary, and imply risks; this leads to a drastic paradigm shift in relation to transfusions and supports the decision to adopt a $25 \times 10^{9} / \mathrm{L}$ threshold for platelets as prophylaxis. In addition, in the future, the decision to perform a prophylactic PT should be individualized, after assessing the different risk factors, rather than based on an arbitrary PC limit. ${ }^{142}$ To this end, it would be necessary to have an algorithm based on a score that measured the bleeding risk, as for adults.

\section{REFERENCES}

1. Sola MC, Christensen RD. Developmental aspects of platelets and disorders of platelets in the neonatal period. In: Christensen RD (ed.). Hematologic Problems of the Neonate. Philadelphia: WB Saunders; 2000.Pages.273-319.

2. Tchernia G, Subtil E, Dehan M, Maurey M, et al. Thrombopenies et infections bacteriennes neo-natales. Nouv Rev FrHematol. 1975; 15(4):484-95.

3. Zipursky A, Jaber HM. The haematology of bacterial infection in thenewborn infant. Clin Haematol. 1978;7(1):17593.

4. Modanlou HD, Ortiz OB. Thrombocytopenia in neonatal infection. Clin Pediatr (Phila). 1981; 20(6):402-7.

5. Murray NA, Roberts IA. Circulating megakaryocytes and their progenitors in early thrombocytopenia in preterm neonates. Pediatr Res. 1996; 40(1):112-9.

6. Sola MC, Clahoun DA, Hutson AD, Christensen RD. Plasma thrombopoietin concentrations in thrombocytopenic and non-thrombocytopenic patients in a neonatal intensive care unit. Br J Haematol. 1999; 104(1):90-2.

7. Hutter JJ, Hathaway WE, Wayne ER. Hematologic abnormalities in severe neonatal necrotizing enterocolitis. J Pediatr. 1976; 88(6):1026-31.

8. Patel CC. Hematologic abnormalities in acute necrotizing enterocolitis. Pediatr Clin North Am. 1977; 24(3):579-84.

9. Ververidis M, Kiely EM, Spitz L, Drake DP, et al. The clinical significance of thrombocytopenia in neonates with necrotizing enterocolitis. J Pediatr Surg. 2001;36(5):799-803.

10. Caplan MS, Sun XM, HseuhW, Hageman JR. Role of platelet activating factor and tumor necrosis factor-alpha in neonatal necrotizing enterocolitis. J Pediatr. 1990; 116(6):960-4.

11. Colarizi P, Fiorucci P, Caradonna A, Ficuccilli F, et al. Circulating thrombopoietin levels in neonates with infection. Acta Paediatr. 1999; 88(3):332-7.

12. Kenton AB, Hegemier S, Smith EO, O'Donovan DJ, et al. Platelet transfusions in infants with necrotizing enterocolitis donot low mortality but may increase morbidity. J Perinatol. 2005; 25(3):173-7.

13. Baer VL, Lambert DK, Henry E, Snow GL, et al. Do platelet transfusions in the NICU adversely affect survival? Analysis of 1600 thrombocytopenic neonates in a multihospital healthcare system. J Perinatol. 2007; 27(12):790-6.

14. Du Pont-Thibodeau G, Tucci M, Robitaille N, Ducruet T, et al. Platelet transfusions in pediatric intensive care. Pediatr Crit Care Med. 2016; 17(9): e420-9.

15. Vázquez L, Donato H. Trastornos hematológicos secundarios a patología materna. In: Donato H, Rapetti MC (eds.). Hematología Neonatal. Buenos Aires: Fundasap; 2007.Pages.309-36.

16. Nelson CT, Demmler GJ. Cytomegalovirus infection in the pregnant mother, fetus, and newborn infant. Clin Perinatol. 1997; 24(1):151-60.

17. Brown HL, Abernathy MP. Cytomegalovirus infection. Semin Perinatol. 1998; 22(4):260-6.

18. Stagno S. Cytomegalovirus. In: Remington JS, Klein JO (eds.). Infectious Diseases of the Fetus and Newborn Infant. Philadelphia: Cambridge University Press; 2001. Pages.389-424.

19. OskiFA, NaimanJW.Problemas Hematológicos enelRecién Nacido. Buenos Aires, Panamericana; 1982.Pages.46-69.

20. Hohlfeld P, Forestier E, Kaplan C, Tissot JD, et al. Fetal thrombocytopenia: a retrospective survey of 5194 fetal blood samplings. Blood. 1994; 84(6):1851-6.

21. Barbi M, Binda S, Primache V, Novelli C. Cytomegalovirus in peripheral blood leukocytes of infants with congenital or postnatal infection. Pediatr Infect Dis J. 1996; 15(10):898903.

22. Chesney PJ, Taher A, Gilbert EMF, Shahidi NT. Intranuclear inclusions in megakaryocytes in congenital cytomegalovirus infection. J Pediatr. 1978; 92(6):957-8.

23. Crapnell K, Zanjani ED, Chaudhuri A, Ascensao JL, et al. In vitro infection of megakaryocytes and their precursors by human cytomegalovirus. Blood. 2000; 95(2):487-93.

24. Arav-Boger R, Reif $S$, Bujanover Y. Portal vein thrombosis caused by protein $C$ and protein $S$ deficiency associated with cytomegalovirus infection. J Pediatr. 1995; 126(4):5868 . 
25. Mizutani K, Azuma E, Komada Y, Ito M, et al. An infantile case of cytomegalovirus induced idiopathic thrombocytopenic purpura with predominant proliferation of CD10 positive lymphoblast in bonemarrow. Acta Paediatr Jpn. 1995; 37(1):71-4.

26. Boppana SB, Pass RF, Britt WJ, StagnoS, et al. Symptomatic congenital cytomegalovirus infection: neonatal morbidity and mortality. Pediatr Infect Dis J. 1992; 11(2):93-9.

27. Rudolph A, Yow M, Phillips C, Desmond MM, et al. Transplacental rubella infection in newly born infants. JAMA. 1965; 191:843-5.

28. Giles JP, Cooper LZ, Krugman S. The rubella syndrome. J Pediatr. 1965; 66:434-7.

29. Cooper LZ, Green RH, Krugman S, Giles JP, et al. Neonatal thrombocytopenic purpura and other manifestations of rubella contracted in utero. Am J Dis Child. 1965;110(4):41627.

30. Korones SB, Ainger LE, Monif GR, Roane J, etal. Congenital rubella syndrome: study of 22 infants. Myocardial damage and other new clinical aspects. Am J Dis Child. 1965; 110(4):434-40.

31. Banatvala JE, Horstmann DM, Payne MC, Gluck L. Rubella syndrome and thrombocytopenic purpura in newborn infants: clinical and virologic observations. $N$ Engl J Med. 1965; 273(9):474-8.

32. Bayer WL, Sherman EE, Michaels RH, Szeto IL, et al. Purpura in congenital and acquired rubella. N Engl J Med. 1965; 273(25):1362-6.

33. Zinkham WH, Medearis DN, Osborn JE. Blood and bone marrow findings in congenital rubella. J Pediatr. 1967; 71(4):512-24.

34. Janner D. Growth retardation, congenital heart disease and thrombocytopenia in a newborn infant. Pediatr Infect Dis J. 1991; 10(11):874-7.

35. Rausen A, London R, Mizrahi A, Cooper LZ. Generalized bone changes and thrombocytopenic purpura in association with intrauterine rubella. Pediatrics. 1965; 36:264-8.

36. Freiman I, Super M. Thrombocytopenia and congenital syphilis in South African Bantu infants. Arch Dis Child. 1966; 41(215):87-90.

37. WhitakerJA, Sartain P, Shaheedy M. Hematological aspects of congenital syphilis. J Pediatr. 1965; 66:629-36.

38. Alford CA, Stagno S, Reynolds DW. Congenital toxoplasmosis: clinical, laboratory, and therapeutic considerations, with special reference to subclinical disease. Bull N Y Acad Sci. 1974; 50(2):160-81.

39. ModlinJF. Fatalechovirus 11 disease in premature neonates. Pediatrics. 1980; 66(5):775-80.

40. Abzug MJ, Levin MJ, Rotbart HA. Profile of enterovirus disease in the first two weeks of life. Pediatr Infect Dis J. 1993; 12(10):820-4.

41. Pruekprasert P, Stout C, Patamasucon P. Neonatal enterovirus infection. J Assoc Acad Minor Phys. 1995; 6(4):1348.

42. Abzug NJ, Johnson SM. Catastrophic intracranial hemorrhage complicating perinatal viral infections. Pediatr Infect Dis J. 2000; 19(6):556-9.

43. Nahmias AJ, Alford CA, Korones SB. Infection of the newborn with herpesvirus hominis. Adv Pediatr. 1970; 17:185-226.

44. Lascari AD, Wallace PD. Disseminated intravascular coagulation in the newborn. Survey and appraisal as exemplified in two case histories. Clin Pediatr (Phila). 1971; 10(1):11-7.

45. Kohl S. Neonatal herpes simplex virus infection. Clin Perinatol. 1997; 24(1):129-50.

46. Arvin AM, Whitley RJ. Herpes simplex viral infections. In: Remington JS, Klein JO (eds.). Infectious Diseases of the
Fetus and Newborn Infant. Philadelphia: WB Saunders; 2001. Pages.425-41.

47. Forestier F, Tissot JD, Vial Y, Daffos F, et al. Haematological parameters of parvovirus B19 infection in 13 fetuses with hydrops foetalis. Br J Haematol. 1999; 104(4):925-7.

48. Abildgaard CF. Recognition and treatment of intravascular coagulation. J Pediatr. 1969; 74(2):163-76.

49. VanVooren DM, Bradshaw WT, Blake SM. Disseminated intravascular coagulation in the neonate. Neonatal Netw. 2018; 37(4):205-11.

50. Levi M, Ten Cate H. Disseminated intravascular coagulation. N Engl J Med. 1999; 341(8):586-92.

51. GeorgeJN. Clinical practice. Thrombotic thrombocytopenic purpura. N Engl J Med. 2006; 354(18):1927-35.

52. Monnens LAH, Retera RJM. Thrombotic thrombocytopenic purpura in a neonatal infant. J Pediatr. 1967; 71(1):118-23.

53. Noris M, Caprioli J, Bresin E, Mossali C, et al. Relative role of genetic complement abnormalities in sporadic and familial aHUS and their impact on clinical phenotype. Clin J Am Soc Nephrol. 2010; 5(10):1844-59.

54. Loirat C, Garnier A, Sellier-Leclerc AL, Kwon T. Plasmatherapy in atypical hemolytic uremic syndrome. Semin Thromb Hemost. 2010; 36(6):673-81.

55. Kasabach HH, Merritt KK. Capillary hemangioma with extensive purpura. Report of a case. Am J Dis Child. 1940; 59:1063-5.

56. Lelong M, Alagille D, Habib EC, Steiner A. L'hémangiome geant du nourrisson avec thrombopenie. Arch Fr Pediatr. 1964; 21:769-84.

57. Shim WKT. Hemangiomas of infancy complicated by thrombocytopenia. Am J Surg. 1968; 116(6):896-906.

58. Seo SK, Suh JC, Na GY, Kim IS, et al. Kasabach-Merritt syndrome: identification of platelet trapping in a tufted angioma by immunohistochemistry technique using monoclonal antibody to CD61. Pediatr Dermatol. 1999; 16(5):392-4.

59. AntovicJ, Bakic M, Milicevic R, Gojkovic G, et al. Activation of the coagulation system occurs within rather than outside cutaneous haemangiomas. Acta Paediatr. 2001;90(10):113740.

60. OskiFA, NaimanJW.Problemas Hematológicosenel Recién Nacido. Buenos Aires: Panamericana; 1982.Pages.188-237.

61. Kasubuchi Y, Sawada T, Nakamura T. Successful treatment of neonatal retroperitoneal hemangioma with corticosteroids. J Pediatr Surg. 1973; 8(1):59-62.

62. Evans J, Batchelor ADR, Stark G, Uttley WS. Hemangioma with coagulopathy: sustained response to prednisone. Arch Dis Child. 1975; 50:809-12.

63. Hagerman LJ, Czapek EE, Donnellan WL, Schwartz AD. Giant hemangioma with consumption coagulopathy. J Pediatr. 1975; 87(5):766-8.

64. Ezekowitz RAB, Mulliken JB, Folkman J. Interferon alpha2a therapy for life-threatening hemangiomas of infancy. $N$ Engl J Med. 1992; 326(22):1456-63.

65. Teillac-Hamel D, De Prost Y, Bodemer C, Andry P, et al. Serious childhood angiomas: unsuccessful alpha- $2 \mathrm{~b}$ interferon treatment: a report of four cases. $\mathrm{Br} J$ Dermatol. 1993; 129(4):473-6.

66. Dubois J, Hershon L, Carmant L, Belanger S, et al. Toxicity profile of interferon alfa- $2 \mathrm{~b}$ in children: a prospective evaluation. J Pediatr. 1999; 135(6):782-5.

67. Burrows PE, Lasjaunias PL, Ter Brugge KG, Flodmark O. Urgent and emergent embolization of lesions of the head and neck in children: indications and results. Pediatrics. 1987; 80(3):386-94.

68. Tan OT, Gilchrest BA. Laser therapy for selected cutaneous vascular lesions in the pediatric population: a review. Pediatrics. 1988; 82(4):652-62. 
69. Chessells JM, Wigglesworth JS. Haemostatic failure in babies with rhesus isoimmunization. Arch Dis Child. 1971; 46(245):38-45.

70. Koenig JM, Christensen RD. Neutropenia and thrombocytopenia in infants with Rh hemolytic disease. J Pediatr. 1989; 114(4 Pt 1):625-31.

71. Saade GR, Moise KJ Jr, Copel JA, Belfort MA, et al. Fetal platelet counts correlate with the severity of the anemia in red-cell alloimmunization. Obstet Gynecol. 1993; 82(6):98791.

72. Maurer HM, Fratkin M, McWilliams NB, Kirkpatrick B, et al. Effects of phototherapy on platelet counts in low-birth weight infants and on platelet production and life span in rabbits. Pediatrics. 1976; 57(4):506-12.

73. Maurer HM, Haggins JC, Still WJS. Platelet injury during phototherapy. Am J Hematol. 1976; 1(1):89-96.

74. De Alarcón P. Newborn platelet disorders. In: De Alarcón P, Werner E (eds.). Neonatal Hematology. Cambridge: Cambridge University Press; 2005.Pages.187-253.

75. Henriksson P. Hyperviscosity of the blood and haemostasis in the newborn infant. Acta Paediatr Scand. 1979; 68(5):7014.

76. Katz J, Rodriguez E, Mandani G, Branson HE. Normal coagulation findings, thrombocytopenia, and peripheral hemoconcentration in neonatal polycythemia. J Pediatr. 1982; 101(1):99-102.

77. Acunas B, Celtik C, Vatansever U, Karasalihoglu S. Thrombocytopenia: an important indicator for the application of partial exchange transfusion in polycythemic newborn infants? Pediatr Int. 2000; 42(4):343-7.

78. Segall ML, Goetzman BW, Schick JB. Thrombocytopenia and pulmonary hypertension in the perinatal aspiration syndromes. J Pediatr. 1980; 96(4):727-30.

79. Meberg A, Jakobsen E, Halvorsen K. Humoral regulation of erythropoiesis and thrombopoiesis in appropriate and small for gestational age infants. Acta Paediatr Scand. 1982; 71(5):769-73.

80. Philip AG, Tito AM. Increased nucleated red blood cell counts in small for gestational age infants with very low birth weight. Am J Dis Child. 1989; 143(2):164-9.

81. Peters M, Ten Cate JW, Koo LH, Breederveld C. Persistent antithrombin III deficiency: risk factor for thromboembolic complications in neonates small for gestational age. JPediatr. 1984; 105(2):310-4.

82. Koyama N, Ohama Y, KanekoK, Itakura Y, etal. Association of neonatal thrombocytopenia and maternal anti-HLA antibodies. Acta Paediatr Jpn. 1991; 33(2):71-6.

83. Murray NA, Watts TL, Roberts IAG. Endogenous thrombopoietin levels and effect of recombinant human thrombopoietin on megakaryocyte precursors in term and preterm babies. Pediatr Res. 1998; 43(1):148-51.

84. Christensen RD, Baer VL, Henry E, Snow GL, et al. Thrombocytopenia in small-for-gestational-age infants. Pediatrics. 2015; 136(2):e361-70.

85. Balduini C, Iolascon A, Savoia A. Inherited thrombocytopenias: from genes to therapy. Haematologica. 2002; 87(8):860-80.

86. Alter BP. Inherited bone marrow failure syndromes. In: Nathan DG, Orkin SH (eds.). Nathan and Oski's Hematology of Infancy and Childhood. Philadelphia: WB Saunders; 2003.Pages.280-342.

87. Muraoka K, Ishii E, Tsuji K, Tamamoto S, et al. Defective response to thrombopoietin and impaired expression of c-mpl mRNA of bone marrow cells in congenital amegakaryocytic thrombocytopenia. Br J Haematol. 1997; 96(2):287-92.

88. Pecci A, Ragab I, Bozzi V, DeRocco D, et al. Thrombopoietin mutation in congenital amegakaryocytic thrombocytopenia treatable with romiplostin. EMBO Mol Med. 2018; 10(1):6375.

89. Gómez S, Donato H, Rapetti MC, Pennesi S. Síndromes de insuficiencia medular. In: Donato H, Rapetti MC, Crisp RL (eds.). Anemias en Pediatría. Buenos Aires: Journal; 2005. Pages.227-60.

90. Alter BP, Young NS. The bone marrow failure syndromes. In: Nathan DG, Orkin SH (eds.). Nathan and Oski's Hematology of Infancy and Childhood. Philadelphia: WB Saunders; 1998.Pages.237-335.

91. Bessler M, Mason PJ, Link DC, Wilson DB. Inherited bone marrow failure syndromes. In: Orkin $\mathrm{SH}$, Fisher DE, Ginsburg D, Look AT, et al (eds.). Nathan and Oski's Hematology and Oncology of Infancy and Childhood. Philadelphia: Elsevier Saunders; 2015.Pages.186:253.

92. King S, Germeshausen M, Strauss G, Welte K, et al. Congenital amegakaryocytic thrombocitopenia: a retrospective clinical analysis of 20 patients. Br J Haematol. 2005; 131(5):636-44.

93. Geddis AE. Congenital amegakaryocytic thrombocitopenia and thrombocytopenia with absent radii. Hematol Oncol Clin North Am. 2009; 23(2):321-31.

94. Hall JG, Levin J, Kuhn JP, Ottenheimer EJ, et al. Thrombocytopenia with absent radius (TAR). Medicine (Baltimore). 1969; 48(6):411-39.

95. Hedberg VA, Lipton JM. Thrombocytopenia with absent radii. A review of 100 cases. Am J Pediatr Hematol Oncol. 1988; 10(1):51-64.

96. Greenhalgh KL, Howell RT, Bottani A, Ancliff PJ, et al. Thrombocytopenia-absent radius syndrome: a clinical genetic study. J Med Genet. 2002; 38(12):876-81.

97. George D, Bussel J. Neonatal thrombocytopenia. SeminThromb Hemost. 1995; 21(3):276-93.

98. Camitta BM, RockA. Acutelymphoidicleukemiain a patient with thrombocytopenia/ absent radii (Tar) syndrome. Am J Pediatr Hematol Oncol. 1993; 15(3):335-7.

99. Fadoo Z, Naqvi SM. Acute myeloid leukemia in a patient with thrombocytopenia with absent radii syndrome. $J$ Pediatr Hematol Oncol. 2002; 24(2):134-5.

100.Go RS, Johnston KL. Acute myelogenous leukemia in an adult with thrombocytopenia with absent radii syndrome. Eur J Haematol. 2003; 70(4):246-8.

101.Balduini C, Cattaneo M, Fabris F, Gresel P, et al. Inherited thrombocytopenias: a proposed diagnostic algorithm from the Italian Gruppo di Studio delle Piastrine. Haematologica. 2003; 88(5):582-92.

102.Balduini CL, Savoia A. Genetics of familial forms of thrombocytopenia. Hum Genet. 2012; 131(12):1821-32.

103.Samelson-Jones BJ, Kramer PM, Chicka M, Gunning WT 3rd, etal.MYH9-macrothrombocytopenia caused by a novel variant (E1421K) initially presenting as apparent neonatal alloimmune thrombocytopenia. Pediatr Blood Cancer. 2018; 65(4):e26949.

104.Pascarella A, Rosa M, Della Casa R, Andria G, etal. Isovaleric academia. J Pediatr Endocrinol Metab. 2011; 24(5-6):399.

105.Morrow G3 ${ }^{\text {rd }}$, BarnessLA, Auerbach VH, DiGeorgeAM, etal. Observations on the coexistence of methylmalonicacidemia and glycinemia. J Pediatr. 1969; 74(5):680-90.

106.Roth KS, Yang W, Foreman JW, Rothman R, et al. Holocarboxylase syntethase deficiency: a biotin-responsive organic acidemia. J Pediatr. 1980; 96(5):845-9.

107.Markenson AL, Hilgartner MW, Miller DR. Transient thrombocytopenia in 18-trisomy. JPediatr. 1975; 87(5):834-5.

108.Kleckner HB, Giles HR, Corrigan JJ Jr. The association of maternal and neonatal thrombocytopenia in high-risk pregnancies. Am J Obstet Gynecol. 1977; 128(3):235-8.

109.Brazy JE, Grimm JK, Little VA. Neonatal manifestations of severe maternal hypertension occurring before the thirty- 
sixth week of pregnancy. J Pediatr. 1982; 100(2):265-71.

110.Sibai BM, Abdella TN, Hill GA, Anderson GD. Hematologic findings in mothers and infants of patients with severe preeclampsia / eclampsia. Clin Exp Hypertens. 1984; 3(1):13-21.

111.Pritchard JA, Cunningham FG, Pritchard SA, Mason RA. How often does maternal preeclampsia-eclampsia incite thrombocytopenia in the fetus? Obstet Gynecol. 1987; 69(3 Pt 1):292-5.

112.Sainio S, Jarvenpää AL, Renlund M, Riikonen S, et al. Thrombocytopenia in term infants: a population-based study. Obstet Gynecol. 2000; 95(3):441-6.

113.Elsas L, Whittemore R, Burrow G. Maternal and neonatal Grave's disease. JAMA. 1967; 200(3):250-2.

114.Andrew M, Vegh P, Caco C, Kirpalani H, et al. A randomized, controlled trial of platelet transfusions in thrombocytopenic premature infants. J Pediatr. 1993; 123(2):285-91.

115.Stanworth SJ, ClarkeP, Watts T, Ballard S, etal. Prospective, observational study of outcomes in neonates with severe thrombocytopenia. Pediatrics. 2009; 124(5):e826-34.

116.Madani K, Kamphuis M, Lopriore E, Porcelijn L, et al. Delayed diagnosis of fetal and neonatal alloimmune thrombocytopenia: a cause of perinatal mortality and morbidity. BJOG. 2012; 119(13):1612-6.

117.Von Lindern JS, Van den Bruele T, Lopriore E, Walther FJ. Thrombocytopenia in neonates and the risk of intraventricular hemorrhage: a retrospective cohort study. BMC Pediatr. 2011; 11:16.

118. Von Lindern J, Hulzebos C, Bos A, Brand Am, et al. Thrombocytopaenia and intraventricular haemorrhage in very premature infants: a tale of two cities. Arch Dis Child Fetal Neonatal Ed. 2012; 97(5):F348-52.

119.Gunnink SF, Vlug R, Fijnvandraat K, Van der Bom J, et al. Neonatal thrombocytopenia: etiology, management and outcome. Expert Rev Hematol. 2014; 7(3):387-95.

120.Sparger K, Deschmann E, Sola-Visner M. Platelet transfusions in the neonatal intensive care unit. Clin Perinatol. 2015; 42(3):613-23.

121.Carr R, Kelly AM, Williamson LM. Neonatal thrombocytopenia and platelet transfusion - A UK perspective. Neonatology. 2015; 107(1):1-7.

122.Fustolo-Gunnink SF, Huijssen EJ, Van der Bom JG, Van Hout FMA, et al. Are thrombocytopenia and platelet transfusions associated with major bleeding in preterm neonates? A systematic review. Blood Rev. 2018; 36:1-9.

123.Del Vecchio A, Motta M, Radicioni M, Christensen RD. A consistent approach to platelet transfusion in the NICU. J Matern Fetal Neonatal Med. 2012; 25(Suppl 5):93-6.

124.Strauss RG, Levy GJ, Sotelo-Avila C, Albanese MA, et al. National survey of neonatal transfusion practices: II. Blood component therapy. Pediatrics. 1993; 91(3):530-6.

125.Josephson CD, Su LL, Christensen RD, Hillyer CD, et al. Platelet transfusion practices among neonatologists in the United States and Canada. Pediatrics. 2009; 123(1):278-85.

126.New HV, Berryman J, Bolton-Maggs PHB, Cantwell C, et al. Guidelines on transfusion for fetuses, neonates and older children. Br J Haematol. 2016; 175(5):784-828.

127.Thomas S. Platelets: handle with care. Transfus Med. 2016; 26(5):330-8.

128.Blanchette VS, Kühne T, Hume H, Hellman J. Platelet transfusion therapy in newborn infants. Transfus Med Rev. 1995; 9(3):215-30.

129. Calhoun DA, Christensen RD, Edstrom CS, Juul SE, et al. Consistent approaches to procedures and practices in neonatal hematology. Clin Perinatol. 2000; 27(3):733-53.

130.Murray NA, Howarth LJ, McCloy MP, Letsky A, et al. Platelet transfusion in the management of severe thrombocytopenia in neonatal intensive care unit patients.
Transfus Med. 2002; 12(1):35-41.

131.Ginson BE, Todd A, Roberts I, Pamphilon D, et al. Transfusion guidelines for neonates and older children. Br J Haematol. 2004; 124(4):433-53.

132.DonatoH. Trastornos delas plaquetas. In:Donato H, Rapetti MC (eds.). Hematología Neonatal. Buenos Aires: Fundasap; 2007.Pages.227-54.

133.Strauss RG. Platelet transfusions in neonates: questions and answers. Expert Rev Hematol. 2010; 3(1):7-9.

134.Dannaway DC, Noori S. A randomized trial of platelet transfusions over 30 vs 120 minutes: in there an effect on post-transfusion platelet counts? J Perinatol. 2013;33(9):7036.

135.Borges JPG, Dos Santos AMN, Da Cunha DHF, Mimica AFMA, et al. Restrictive guideline reduces platelet count thresholds for transfusions in very low birth weight preterm infants. Vox Sang. 2013; 104(3):207-13.

136.Curley A, Stanworth SJ, Willoughby K, Fustolo-Gunnink $\mathrm{SF}$, et al. Randomized trial of platelet-transfusion threshold in neonates. N Engl J Med. 2019; 380(3):242-51.

137.Patel RM, Josephson C. Neonatal and pediatric platelet transfusions: current concepts and controversies. Curr Opin Hematol. 2019; 26(6):466-72.

138.La Gamma EF, Blau J. Transfusion-related acute gut injury: feeding, flora, flow, and barrier defense. Semin Perinatol. 2012; 36(4):294-305.

139.Garcia MG, Duenas E, Sola MC, Hutson AD, et al. Epidemiologic and outcome studies of patients who received platelet transfusions in the neonatal intensive care unit. J Perinatol. 2001; 21(7):415-20.

140.Baer VL, Lambert DK, Henry E, Christensen RD. Severe thrombocytopenia in the NICU. Pediatrics 2009; 124(6):e1095-100.

141.Lieberman L, Petraszko T, Yi QL, Hannach B, et al. Transfusion-related lung injury in children: a case series and review of the literature. Transfusion. 2014; 54(1):57-64.

142.Cremer M, Sallmon H, King PJ, Bührer C, et al. Thrombocytopenia and platelet transfusion in the neonate. Semin Fetal Neonatal Med. 2016; 21(1):10-8.

143.Schmidt AE, Henrichs KF, Kirkley SA, Refaai MA, et al. Prophylactic preprocedure platelet transfusion is associated with increased risk of thrombosis and mortality. Am J Clin Pathol. 2017; 149(1):87-94.

144.Baharoglu MI, Cordonnier C, Al-Shahi Salman R, De Gans $\mathrm{K}$, et al. Platelet transfusion versus standard care after acute stroke due to spontaneous cerebral haemorrhage associated with antiplatelet therapy (PATCH): a randomised, openlabel, phase 3 trial. Lancet. 2016; 387(10038):2605-13.

145.Kasotakis G, Starr N, Nelson E, Sarkar B, et al. Platelet transfusion increases risk for acute respiratory distress syndrome in non-massively transfused blunt trauma patients. Eur J Trauma Emerg Surg. 2019; 45(4):671-9.

146.Zhou X, Fraser CD 3rd, Suárez-Pierre A, Crawford TC, et al. Variation in platelet transfusion practices in cardiac surgery. Innovations (Phila). 2019; 14(2):134-43.

147.Zeller MP, Al-Habsi KS, Heddle NM. Prophylactic platelet transfusions: should they be a treatment of the past? Curr Opin Hematol. 2014; 21(6):521-7.

148.Kremke M, Hansen MK, Christensen S, Tang M, et al. The association between platelet transfusion and adverse outcomes after coronary artery bypass surgery. Eur J Cardiothorac Surg. 2015; 48(5):e102-9.

149.Ninkovic S, McQuilten Z, Gotmaker R, Newcomb AE, et al. Platelet transfusion is not associated with increased mortality or morbidity in patients undergoing cardiac surgery. Transfusion. 2018; 58(5):1218-27.

150.Newland A, Bentley R, Jakubowska A, Liebman H, et al. A systematic literature review on the use of platelet 
transfusions in patients with thrombocytopenia. Hematology. 2019; 24(1):679-719.

151.Stainsby D, Jones H, Wells AW, Gibson B, et al. Adverse outcomes of blood transfusion in children: analysis of UK reports to the serious hazards of transfusion scheme 19962005. Br J Haematol. 2008; 141(1):73-9.

152.Steinsvag CT, Espinosa A, Flesland O. Eight years with haemovigilance in Norway. What have we learnt? Transfus Apher Sci. 2013; 49(3):548-52.

153.Akkök CA, Seghatchian J. Pediatric red cell and platelet transfusions. Transfus Apher Sci. 2018; 57(3):358-62.

154.O'Leary H, Gregas MC, Limperopoulos C, Zaretskaya I, et al. Elevated cerebral pressure passivity is asociated with prematurity-related intracranial hemorrhage. Pediatrics. 2009; 124(1):302-9.

155.Fustolo-Gunnink SF, Roehr CC, Lieberman L, Christensen $\mathrm{RD}$, et al. Platelet and red cell transfusions for neonates: lifesavers or Trojan horses? Expert Rev Hematol. 2019; 12(10):797-800.

156.Curley A, Stanworth SJ, New H. A randomized trial of neonatal platelet transfusion thresholds. Reply. $N$ Engl J Med. 2019; 380(16):1584-5.

157.Israels SJ, Cheang T, McMillan-Ward EM, Cheang M.
Evaluation of primary hemostasis in neonates with a new in vitro platelet function analyzer.J Pediatr. 2001;138(1):1169.

158.Sitaru AG, Holzhauer S, Speer CP, Singer D, et al. Neonatal platelets from cord blood and peripheral blood. Platelets. 2005; 16(3-4):203-10.

159.Bednarek FJ, Bean S, Barnard MR, Frelinger AL, et al. The platelet hyporeactivity of extremely low birth weight neonates is age-dependent. Thromb Res. 2009; 124(1):42-5.

160.Margraf A, Nussbaum C, Sperandio M. Ontogeny of platelet function. Blood Adv. 2019; 3(4):692-703.

161.Moore CM, Curley A. Platelet transfusion thresholds in neonatal medicine. Early Hum Dev. 2019; 138:104845.

162.Stanworth SJ. Thrombocytopenia, bleeding, and use of platelet transfusions in sick neonates. Hematology Am Soc Hematol Educ Program. 2012; 2012:512-6.

163.McFadyen JD, Kaplan ZS. Platelets are not just for clots. Transfus Med Rev. 2015; 29(2):110-9.

164.Stolla M, Refaai MA, Heal JM, Spinelli SM, et al. Platelet transfusion - the new immunology of an old therapy. Front Immunol. 2015; 6:28.

165.Fernandes CJ, O'Donovan DJ. Platelet transfusions in infants with necrotizing enterocolitis. Curr Hematol Rep. 2006; 5(1):76-81. 